\title{
Characterization of the Agricultural Supply of Desalinated Seawater in Southeastern Spain
}

\author{
Victoriano Martínez-Alvarez *(D, Jose F. Maestre-Valero, Manuel J. González-Ortega, \\ Belén Gallego-Elvira $₫$ and Bernardo Martin-Gorriz \\ Agricultural Engineering Center, Technical University of Cartagena, Paseo Alfonso XIII 48, \\ 30203 Cartagena, Spain; josef.maestre@upct.es (J.F.M.-V.); iamjgonzalez@gmail.com (M.J.G.-O.); \\ belen.gallego@upct.es (B.G.-E.); b.martin@upct.es (B.M.-G.) \\ * Correspondence: victoriano.martinez@upct.es; Tel.: +34-968-325-473
}

Received: 30 April 2019; Accepted: 12 June 2019; Published: 13 June 2019

check for updates

\begin{abstract}
The increasing shortage of water for crop irrigation in arid and semiarid regions is encouraging the use of non-conventional resources. In the last decade, seawater desalination has consolidated its position as an alternative source to increase the supply for agricultural irrigation in Spain and Israel, where the farmers' acceptance is progressively rising, despite the supply price being much higher than that of other conventional water sources. This article describes the current situation of desalinated seawater production and supply to agriculture in the southeast of Spain, and analyzes key questions such as its role in regional water planning, the infrastructure needed for conveyance and distribution, the energy requirements, the production and distribution costs, and the final price to farmers. The study is based on descriptive and quantitative data collected from desalination plants and irrigation district managers through technical questionnaires and personal interviews. The results show how seawater desalination is effectively alleviating the regional constraints in the irrigated agriculture supply, and why it is becoming strategic to maintaining food production and socioeconomic development. However, the high-energy requirements and associated costs in comparison with other water sources limit a more widespread use for agriculture, and for this reason desalinated water still only plays a complementary role in most irrigation districts.
\end{abstract}

Keywords: desalination; crop irrigation; energy consumption; water price; agriculture resilience

\section{Introduction}

Population growth, economic, social and urban development, and, especially, the development of irrigated agriculture in response to the growing demand for food, are the main drivers of the water demand increase in Mediterranean countries [1]. This has led to water undersupply in some regions and increased pressure on water resources, which often result in conflicts among users [2]. Moreover, climate change prospects for Mediterranean countries suggest that the situation is likely to worsen in the near future [3]. Irrigated agriculture is the sector that is most affected by water scarcity, as it currently accounts for $70 \%$ of global freshwater withdrawals and more than $90 \%$ of consumptive use [4]. Therefore, increasing water scarcity poses a serious threat for agricultural production in Mediterranean countries, as well as in other arid and semi-arid regions.

Innovative initiatives to promote the resilience of irrigated agriculture to the progressive depletion of natural hydrological systems (surface and groundwater) are required, such as the adoption of non-conventional water resources. In particular, water reclamation and seawater desalination for agriculture are on the rise in reaction to the increasing water shortage [5]. In fact, desalinated seawater (DSW) as an alternative source to increase the water supply for crop irrigation has only emerged in 
Israel and Spain during the last decade [6], where its acceptance by farmers is progressively growing, although its supply price is several times higher than that of traditional water sources [7].

Seawater desalination can be a cross sectoral measure for alleviating the water shortage crisis. Nowadays, $7.5 \%$ ( $551.6 \times 10^{6}$ people) of the world's population relies on domestic desalinated seawater supply, and this is expected to rise to $18 \%\left(1768 \times 10^{6}\right.$ people) by 2050 [8]. Seawater desalination has also been recognized as a realistic technological choice to augment the supply of water for irrigated agriculture in coastal areas. Initial experiences with DSW for crop irrigation have highlighted its main strengths $[7,9,10]$ : (i) it is an unlimited agricultural water supply, which additionally provides drought risk-buffering value; (ii) its low salinity can produce significant increases in the quality and quantity of crop yields, especially when replacing low quality water supplies in water stressed regions; and (iii) the replacement of traditional water sources with DSW provides new water policies and water management options. The principal concerns are: (i) the high energy consumption, which results in considerably higher costs than for other water supply options [7]; (ii) the boron concentration, which is above the threshold for sensitive crops, implying toxicity risks [11]; and (iii) the exacerbation of the water-energy nexus in DSW production, i.e., high greenhouse gas emissions that feed the climate change processes [6]. Moreover, the impact of the disposal of the elevated salinity brines on oceanic life and the risk to marine ecosystems of the release of chemicals used in desalination processes through the brine are also important general environmental concerns in seawater desalination [12,13]. Considering its pros and cons, the integration of DSW for agricultural use with traditional water sources would favor their economic viability, mitigate the agronomic risks and, ultimately, contribute to the sustainability of irrigation [14-16]. Moreover, agricultural DSW consolidation is expected in the coming years, with the advent of new technology and equipment that may reduce desalination costs [17].

Spain is the first country in Europe and third in the world in installed capacity, but also is a pioneer in the management of this resource, incorporating it into the hydrological planning [18]. The integration of DSW into the hydrological planning can enable other resources under high pressure to be released, improving the state of water bodies and preventing water from being a limiting factor for development. In this sense, seawater desalination is the main strategy included in the Spanish water planning schemes in order to cope with the water deficit of stressed regions. In particular, it was brought forward as a possible solution for Southeastern Spain (SE Spain), where the lack of water strongly affects irrigated agriculture and threatens socio-economic development. Today, SE Spain is successfully integrating DSW to ensure sustainable crop production, and is drawing international attention as an example of irrigated agriculture resilience. Conversely, in other Spanish Mediterranean regions where DSW production is devoted to urban supply, seawater desalination plants (SWDPs) are typically underused [9].

In accordance with the significant and increasing global water demands for irrigated agriculture, and the potential role of seawater desalination in meeting these demands in the context of growing water scarcity, it is instructive to describe and analyze the evolution and the current situation of DSW agricultural use in SE Spain. We first describe the main regional water planning characteristics, particularly the role of seawater desalination. Then, we analyze the desalination facilities and the allocation infrastructures involved in DSW production and supply to irrigated agriculture. Finally, we focus our study on technical questions, such as the energy requirements, the associated costs and the DSW final price to farmers. Although some of these issues have already been dealt with $[7,9,19]$, the updated regional analysis presented herein unveils the drastic changes triggered by a recent drought period (2015-2018). This shortage scenario has led to an unprecedented incorporation of DSW to irrigated agriculture, taking a 180-degree turn after the underutilization of the desalination facilities during the relatively wet period in 2010-2014.

The experience described demonstrates that DSW may be a solution to effectively remove the water constraints for irrigated agriculture in coastal regions facing persistent water scarcity. In spite of the high-energy requirements and associated costs in comparison with other water sources, which still limit its widespread use, the complementary role of DSW supply for crop irrigation is contributing to 
maintain food production in many irrigation districts in SE Spain. In fact, it is enabling the farming of high-return crops, for which highly effective water use and farming technologies have already been implemented, and thereby ensuring the regional socioeconomic prosperity.

\section{Study Area and Data Sources}

\subsection{Water Management in the Study Region}

The study region comprises two river basin districts in SE Spain (Figure 1): the Segura River Basin (SRB) and the Andalusian Mediterranean Basins (AMB). The SRB is a predominantly agricultural region, where the adoption of the most efficient irrigation technologies is widespread (drip irrigation represents more than $90 \%$ ) and vegetables can be grown in the open field during winter due to its mild climate conditions. This area is a model of high-return agriculture which is referred to as 'the orchard of Europe' [20]. The official water resources available in the SRB amount to $1602 \mathrm{Mm}^{3} /$ year, which include surface and groundwater resources ( $854 \mathrm{Mm}^{3} /$ year), water transferred from Central Spain through the inter-basin Tajo-Segura (T-S) aqueduct (322 $\mathrm{Mm}^{3} /$ year), reclaimed water (144 Mm $3 /$ year),

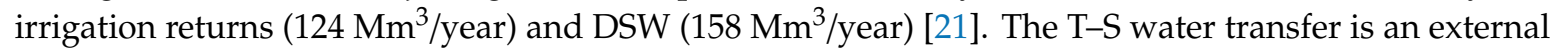
supply (300 km long channel, see Figure 1) that became operational in 1979. It has its own operation rules, which depend on the water availability in the reservoirs located at the headwaters of the Tajo River. Due to the increase in the frequency and severity of droughts, the annual transferred flow is decreasing as climate change pressure mounts [22]. Water resources availability fails to satisfy the total water demand in the basin, which is estimated at $1834 \mathrm{Mm}^{3} /$ year. This includes irrigated agriculture (1546 $\mathrm{Mm}^{3} /$ year), urban supply (236 $\mathrm{Mm}^{3} /$ year), industrial uses $\left(20 \mathrm{Mm}^{3} /\right.$ year) and environmental requirements ( $32 \mathrm{Mm}^{3} /$ year). Considering that not all resources can be used (not regulated streams, flash floods, low quality waters, etc.) there is a water deficit of about $400 \mathrm{Mm}^{3} /$ year, which directly impacts irrigated agriculture. The current irrigated land (262,393 ha) is the result of its vast expansion over the last 40 years, which was mainly based on over-optimistic expectations about the water that would be supplied by the T-S water transfer, and has led to a serious problem of aquifer overexploitation [23].

The AMB is composed of those river basins completely located in the Andalusia region that discharge directly into the Mediterranean. Since irrigation with DSW only occurs in its eastern part (Almeria area), the description of water management characteristics focuses in this area, which corresponds to $44 \%$ of the AMB. The available water resources amount to $344 \mathrm{Mm}^{3} /$ year, which include surface and groundwater resources $\left(257 \mathrm{Mm}^{3} /\right.$ year), water transferred from several external systems (41 $\mathrm{Mm}^{3} /$ year), reclaimed water $\left(11 \mathrm{Mm}^{3} /\right.$ year), and DSW (35 $\mathrm{Mm}^{3} /$ year) [24]. External transfers also include a small portion of the T-S supply and a specific transfer from the adjacent Guadalquivir River Basin (Negratín water transfer). As in the case of SRB, these water sources do not satisfy the water demand, which amounts to $510 \mathrm{Mm}^{3} /$ year, including irrigated agriculture ( $429 \mathrm{Mm}^{3} /$ year), urban supply ( $74 \mathrm{Mm}^{3} /$ year) and industrial uses ( $7 \mathrm{Mm}^{3} /$ year) [22]. A resulting water deficit of $166 \mathrm{Mm}^{3} /$ year has also caused a high degree of overexploitation of groundwater resources. The eastern part of the AMB is characterized by intensive horticulture and the presence of high-tech greenhouses that continuously incorporate technological innovations (e.g., soil-less cultivation, hydroponics, and biological pest and disease control). The greenhouse area has progressively increased in the last 50 years, currently covering an area of 31,034 ha, of which 26,590 ha are under biological production [25].

As a whole, SE Spain has a remarkable agricultural sector that is mainly dedicated to growing fruits and vegetables to export to Europe and, consequently, has great importance in the regional economy, both in terms of value of production and generation of employment [26]. Therefore, irrigated agriculture resilience in SE Spain is very important from a regional socio-economic point of view. The continuous water scarcity pressure that threatens this strategic agricultural production explains the search for alternative water sources and why Spain has been one of the first countries in implementing massive seawater desalination for direct agricultural supply. In this context, the Spanish Government sanctioned the so-called 'AGUA Program' in 2004. This plan, while including some water-saving 
and efficiency improvement initiatives, was mainly aimed at building 21 high-volume SWDPs for the production of $1063 \mathrm{Mm}^{3}$ /year of DSW to supply agricultural, urban and tourist industry uses. More details about the 'AGUA Program' design and implementation can be found in [27,28].

In general, agricultural water management in SE Spain is organized into three levels; first the regional water agency (SRB or AMB) manages and allocates collective water concessions to irrigation districts (farmers associations); then, irrigation districts distribute and supply water to the farmers' plots; and finally, the farmers manage irrigation water with their own on-farm facilities.

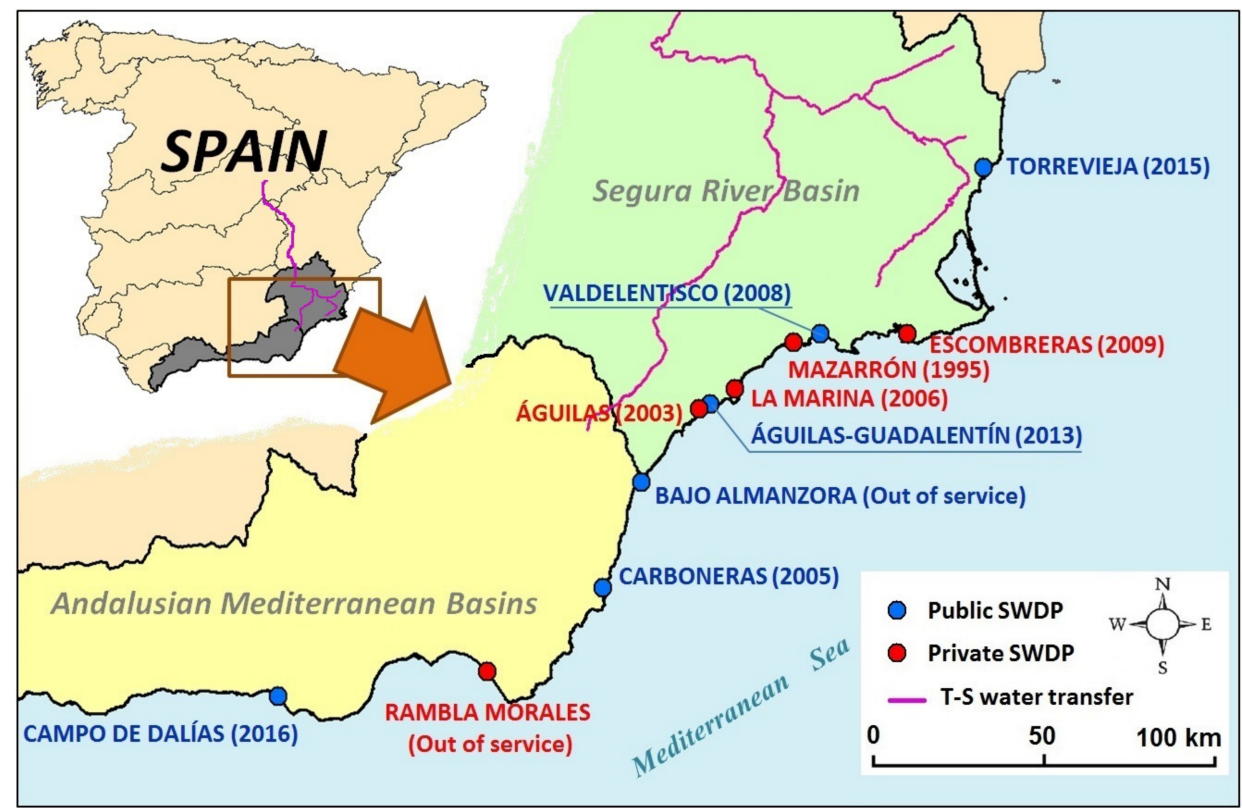

Figure 1. Location of seawater desalination plants (SWDPs) suppling water for agriculture in Southeastern Spain (SE Spain). State-owned SWDPs are shown in blue and private ones in red. Figures in brackets indicate the installation date and those that are currently out of service. The Tajo-Segura (T-S) water transfer system is also depicted in purple.

\subsection{Sources of Information}

The documentation process for the study was carried out in several steps. First, a suitable set of variables was selected for characterizing (1) the current situation and the performance over time of DSW production for agricultural supply, and (2) the infrastructure involved in DSW conveyance and distribution to irrigation districts and farmers. Second, this information was included in a first version of a questionnaire, which was reviewed by a group of experts from different institutions who were collaborating with the personnel involved in the LIFE project DESEACROP ("Desalinated Seawater for alternative and sustainable soilless crop production" [29]). The final reviewed version included 50 questions organized into seven sections: identification and administrative (e.g., name, location, start-up year, ownership, operating company, and investment); design and exploitation (e.g., capacity, specific energy consumption in different stages, pre-treatment, reverse osmosis stages/passes, conversion factor, and energy recovery system); characteristics of raw water (e.g., electric conductivity, and type of intake); characteristics of product water (electric conductivity, $\mathrm{pH}$, chemical composition); historical DSW production and destination (domestic or agricultural use); production costs and supply price (amortization and financial costs, operation and maintenance costs, distribution costs, selling price, taxes, conveyance tolls); and main characteristics of delivery and distribution systems for agricultural supply e.g., (investment, length, storage capacity, main crops, and supplied area). Finally, in order to obtain the descriptive and quantitative information about the selected variables, all SWDPs supplying DSW for agriculture were contacted, as were the main irrigation districts supplied with DSW. In this way, during the second half of 2017 and the beginning of 2018, eight SWDPs (out of a total 
of 11 identified) and seven irrigation districts (out of a total of 10 contacted) were visited to interview their managers and give them the questionnaire for completion.

Therefore, the information used in this article is mainly real operational data for 2017 collected from interviews conducted during the visits and the questionnaires described above. In some cases, when the response did not address all of the survey questions or only poor information was obtained, other secondary sources were used, such as informal conversations with water planners and managers in the region, official annual reports provided by the desalination companies, conference presentations, and other related published literature.

\section{Results and Discussion}

\subsection{Desalinated Seawater Production and Supply to Agriculture}

Eleven SWDPs supply water for agriculture in SE Spain (Figure 1), although two of them are currently out of service for different reasons, as detailed below. Seven are located in the SRB district, while the remaining four belong to the AMB district.

Table 1 summarizes the main characteristics of the SWDPs, as well as the corresponding irrigated area and the length and storage capacity of the delivery and distribution systems for agricultural supply. The total investment in SWDPs and the associated distribution systems amounts to more than $1500 \mathrm{M} €$ for a total production capacity of $362 \mathrm{Mm}^{3} /$ year, of which up to $268.3 \mathrm{Mm}^{3} /$ year could be used for irrigation. The irrigation districts that receive water from these SWDPs grow high-return crops such as greenhouse vegetables (tomato and pepper), winter vegetables in the open field (lettuce and broccoli) and citrus orchards. This gives a total area of 172,000 ha; this figure is lower than the surface sum in Table 1 since some of the irrigation districts are supplied by several SWDPs. 
Table 1. Main characteristics of the SWDPs supplying water for irrigation in Southeastern Spain (SE Spain) in 2017.

\begin{tabular}{|c|c|c|c|c|c|c|c|c|c|c|c|}
\hline \multirow[b]{2}{*}{$\begin{array}{l}\text { Desalination } \\
\text { Plant } \\
\text { (SWDP) }\end{array}$} & \multirow[b]{2}{*}{$\begin{array}{l}\text { Hydrographic } \\
\text { Demarcation }\end{array}$} & \multirow[b]{2}{*}{$\begin{array}{l}\text { Start-Up } \\
\text { Year }\end{array}$} & \multirow[b]{2}{*}{ Owner } & \multirow[b]{2}{*}{$\begin{array}{l}\text { Investment } \\
\text { in SWDP } \\
\text { (ME) }\end{array}$} & \multirow{2}{*}{$\begin{array}{c}\text { Total } \\
\text { Production } \\
\text { Capacity } \\
\text { ( } \mathrm{Mm}^{3} / \text { year) }\end{array}$} & \multirow{2}{*}{$\begin{array}{l}\text { Capacity } \\
\text { for } \\
\text { Irrigation } \\
\left(\mathrm{Mm}^{3} / \text { year) }\right.\end{array}$} & \multirow[b]{2}{*}{$\begin{array}{l}\text { Supplied } \\
\text { Irrigated } \\
\text { Area (ha) }\end{array}$} & \multirow[b]{2}{*}{ Main Crops } & \multicolumn{3}{|c|}{ Distribution System for Irrigation } \\
\hline & & & & & & & & & $\begin{array}{l}\text { Investment } \\
\quad(\mathrm{ME})\end{array}$ & $\begin{array}{l}\text { Length } \\
(\mathbf{k m})\end{array}$ & $\begin{array}{c}\text { Storage } \\
\text { Capacity } \\
\left(\mathrm{Mm}^{3}\right)\end{array}$ \\
\hline $\begin{array}{l}\text { Mazarrón } \\
\text { (Virgen del } \\
\text { Milagro) }\end{array}$ & Segura Basin & 1995 & $\begin{array}{c}\text { Mazarrón } \\
\text { irrigation district }\end{array}$ & 19 & 16 & $16(100 \%)$ & 3595 & $\begin{array}{l}\text { Tomato in } \\
\text { greenhouse, } \\
\text { citrus trees }\end{array}$ & 11 & 103 & $\begin{array}{l}0.9 \text { in } 9 \\
\text { reservoirs }\end{array}$ \\
\hline Águilas & Segura Basin & 2003 & $\begin{array}{c}\text { Águilas } \\
\text { irrigation district }\end{array}$ & - & 8 & $8(100 \%)$ & 5524 & $\begin{array}{c}\text { Tomato in } \\
\text { greenhouse, lettuce }\end{array}$ & - & $>100$ & $\begin{array}{c}0.40 \text { in } 5 \\
\text { reservoirs }\end{array}$ \\
\hline La Marina & Segura Basin & 2006 & $\begin{array}{l}\text { La Marina } \\
\text { irrigation district }\end{array}$ & 13 & 5 & $4.8(95 \%)$ & 1200 & $\begin{array}{c}\text { Tomato in } \\
\text { greenhouse, citrus } \\
\text { trees }\end{array}$ & 1 & 5 & $\begin{array}{l}0.75 \text { in } 3 \\
\text { reservoirs }\end{array}$ \\
\hline Valdelentisco & Segura Basin & 2008 & $\begin{array}{l}\text { ACUAMED } \\
\text { (Spanish } \\
\text { Government) }\end{array}$ & 128 & 48 & $37(77 \%)$ & 21,340 & $\begin{array}{l}\text { Winter vegetables, } \\
\text { citrus trees }\end{array}$ & 96 & $>100$ & $\begin{array}{l}2.60 \text { in } 4 \\
\text { reservoirs }\end{array}$ \\
\hline Escombreras & Segura Basin & 2009 & $\begin{array}{l}\text { Hydro Management } \\
\text { company }\end{array}$ & 117 & 21 & $20.5(98 \%)$ & 15,352 & $\begin{array}{l}\text { Winter vegetables, } \\
\text { citrus trees }\end{array}$ & * & 56 & $\begin{array}{l}0.025 \text { in } 1 \\
\text { reservoir }\end{array}$ \\
\hline $\begin{array}{l}\text { Águilas- } \\
\text { Guadalentín }\end{array}$ & Segura Basin & 2013 & $\begin{array}{l}\text { ACUAMED } \\
\text { (Spanish } \\
\text { Government) }\end{array}$ & 203 & 70 & $58(83 \%)$ & 30,751 & $\begin{array}{l}\text { Citrus trees, } \\
\text { lettuce, tomato }\end{array}$ & 44 & 36 & $\begin{array}{l}0.12 \text { in } 1 \\
\text { reservoir }\end{array}$ \\
\hline Torrevieja & Segura Basin & 2014 & $\begin{array}{l}\text { ACUAMED } \\
\text { (Spanish } \\
\text { Government) }\end{array}$ & 264 & 80 & $40(50 \%)$ & 42,319 & $\begin{array}{l}\text { Winter vegetables, } \\
\text { citrus trees }\end{array}$ & 29 & 21 & $\begin{array}{l}246 \text { in } \\
1 \text { dam }\end{array}$ \\
\hline Carboneras & $\begin{array}{l}\text { Andalusian } \\
\text { Mediterranean } \\
\text { Basins }\end{array}$ & 2005 & $\begin{array}{l}\text { ACUAMED } \\
\text { (Spanish } \\
\text { Government) }\end{array}$ & 132 & 42 & $24.5(58 \%)$ & 18,500 & $\begin{array}{c}\text { Vegetables in } \\
\text { greenhouse, mainly } \\
\text { tomato }\end{array}$ & 226 & 120 & $\begin{array}{l}0.6 \text { in } 6 \\
\text { reservoirs }\end{array}$ \\
\hline $\begin{array}{l}\text { Campo de } \\
\text { Dalías }\end{array}$ & $\begin{array}{c}\text { Andalusian } \\
\text { Mediterranean } \\
\text { Basins }\end{array}$ & 2016 & $\begin{array}{l}\text { ACUAMED } \\
\text { (Spanish } \\
\text { Government) }\end{array}$ & 130 & 30 & $22.5(75 \%)$ & 22,000 & $\begin{array}{l}\text { Vegetables in } \\
\text { greenhouse, } \\
\text { mainly pepper }\end{array}$ & $* *$ & 40.7 & $\begin{array}{l}0.4 \text { in } 5 \\
\text { reservoirs }\end{array}$ \\
\hline $\begin{array}{l}\text { Rambla } \\
\text { Morales }\end{array}$ & $\begin{array}{c}\text { Andalusian } \\
\text { Mediterranean } \\
\text { Basins }\end{array}$ & - & $\begin{array}{l}\text { Rambla Morales } \\
\text { irrigation district }\end{array}$ & 39 & 22 & $22(100 \%)$ & 3300 & $\begin{array}{l}\text { Vegetables in } \\
\text { greenhouse, } \\
\text { mainly tomato }\end{array}$ & - & - & - \\
\hline $\begin{array}{c}\text { Bajo } \\
\text { Almanzora }\end{array}$ & $\begin{array}{l}\text { Andalusian } \\
\text { Mediterranean } \\
\text { Basins }\end{array}$ & - & $\begin{array}{l}\text { ACUAMED } \\
\text { (Spanish } \\
\text { Government) }\end{array}$ & 88 & 20 & $15(75 \%)$ & 24,000 & $\begin{array}{l}\text { Tomato greenhouse } \\
\text { and melon }\end{array}$ & $* *$ & 15.3 & $\begin{array}{l}0.08 \text { in } 1 \\
\text { reservoir }\end{array}$ \\
\hline
\end{tabular}

${ }^{*}$ Capacity for irrigation represents the amount of desalinated seawater (DSW) planned for direct agricultural supply. The percentage with respect to the total capacity is indicated in

brackets. ${ }^{* *}$ The distribution system investment is included in the DSWP investment. Data from questionnaires, [30] and [31]. 
Figure 2 shows the evolution of agricultural DSW supply in SE Spain since 2005. The supply remained below $20 \mathrm{Mm}^{3}$ /year until 2010, when it began to increase quickly, especially from 2015 . This strong growth was mainly caused by the incorporation of the main public SWDPs from 2013 onwards, as private production only bounced back slightly in recent years. The total DSW supply for irrigation in 2017 was $148.3 \mathrm{Mm}^{3}$ in the SRB (9.6\% of its total agricultural demand), and $29.0 \mathrm{Mm}^{3}$ in the AMB (5.9\% of its total agricultural demand), which together amounted to $177.3 \mathrm{Mm}^{3} /$ year for SE Spain, a $66 \%$ of the maximum allocation intended for irrigation $(77 \%$ when out of service SWDPs are not considered). This figure is similar to the agricultural supply of DSW in Israel during the period 2015-2017, which was estimated at $200 \mathrm{Mm}^{3} /$ year, about $40 \%$ of the national freshwater irrigation consumption [16].

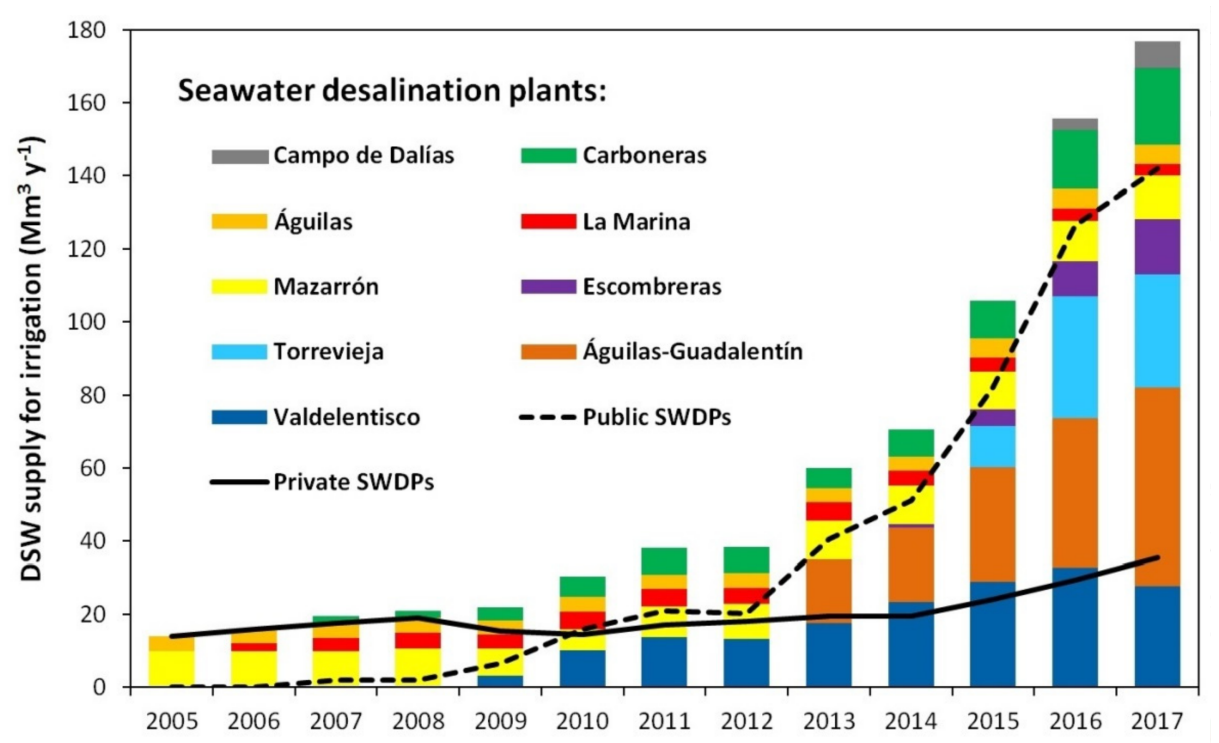

Figure 2. Evolution of agricultural desalinated seawater (DSW) supply in SE Spain by SWDP. Total production in public and private SWDPs is also depicted.

Figure 3 presents the evolution of several water resources in the SRB, along with the agricultural DSW supply in the SRB and the AMB since 2005. The supply drop from the T-S water transfer is apparent during the two drought periods. The first was in 2006-2008, when no reaction is observed in DSW supply since most public SWDPs were still being designed or under construction. Then, when most of them became operational (2009-2014, see Table 1), a wet period in Central Spain meant that abundant resources were available for the T-S water transfer, so although their production was steadily growing, it remained relatively low with respect to their total capacity. The second drought period began in 2015 and clearly brought public DSW production out of its lethargy. The reactivation of DSW production was far more important in the SRB than in the AMB, since the T-S water transfer mainly supplies this basin (see Figure 1), whereas irrigation districts in the AMB are mainly supplied with groundwater, a water resource that is less sensitive to drought periods than the T-S water transfer. As a result, SWDPs were supplying agriculture at near full capacity in the SRB in late 2017, but only at about $72 \%$ capacity in the AMB, despite the fact that two plants were out of service. The major growth of DSW agricultural supply in the SRB meant that, for the first time, DSW surpassed the volume of reclaimed water in 2017. This is a relevant fact considering that the SRB recycles nearly $100 \%$ of wastewater for irrigation [32].

It should be noted that the agricultural sector in the SRB has demanded even more DSW than that supplied in this last drought period, but the need to guarantee the domestic supply limited the amount of DSW allocated for irrigation (see Figure 3). As the agricultural DSW demand is only being partially satisfied, several farmer associations and coastal irrigation districts are promoting the construction of new private SWDPs through collective projects [33,34]. 


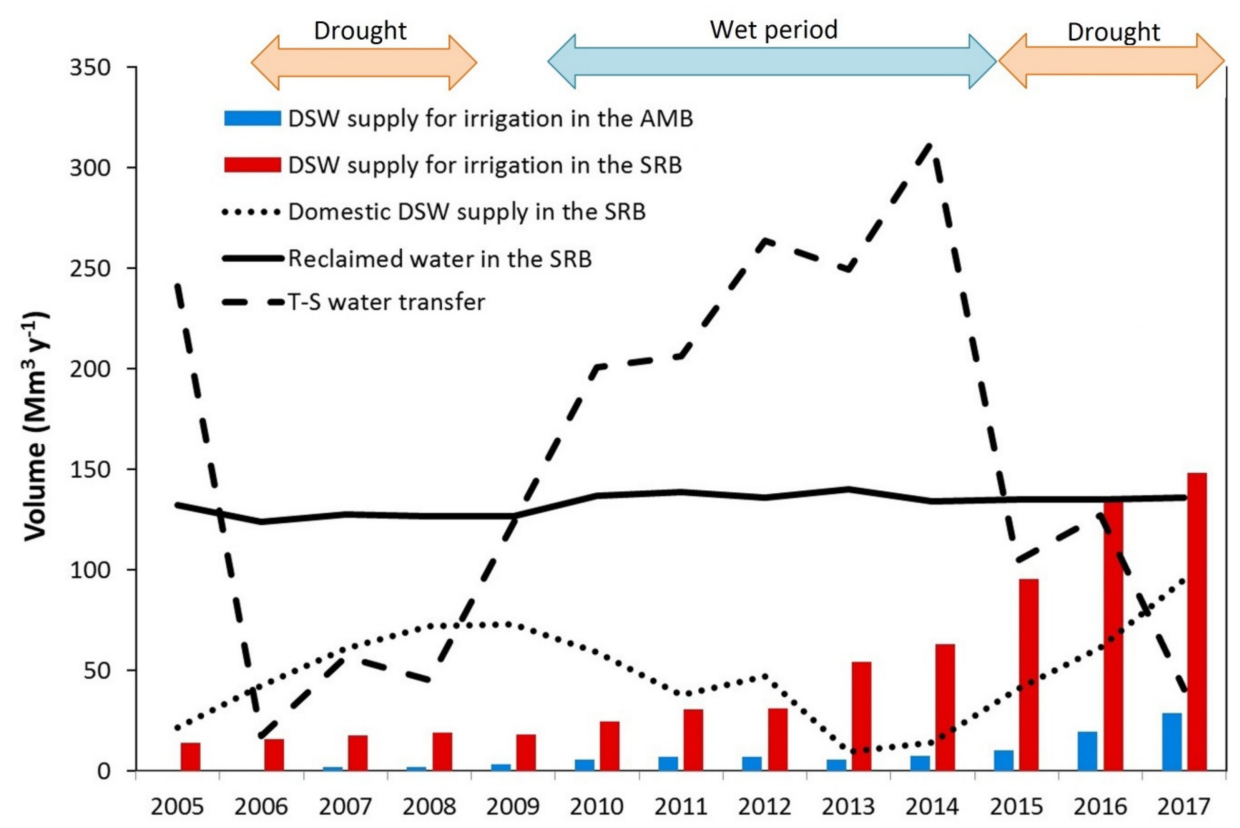

Figure 3. Evolution of domestic and agricultural DSW supply, reclaimed water use, and Tajo-Segura transferred water in the Segura River Basin (SRB). Agricultural DSW supply in the Andalusian Mediterranean Basins (AMB) is also depicted.

\subsection{Energy Consumption of DSW for Agriculture}

Reverse osmosis technology has emerged in the last decades as the leading technology for large-scale seawater desalination because of its relatively low energy consumption and production costs, compared to other alternatives [9,35]. However, reverse osmosis is still characterized by high energy requirements in comparison with those of other water supplies for irrigation in SE Spain [36], which represents a barrier to its implementation for crop irrigation. Moreover, the agricultural DSW supply can prove even more energy demanding than the domestic supply, due to the requirements for its conveyance to irrigation districts, and the additional post-treatment requirements for boron removal for sensitive crops [37]. Consequently, the energy needs for DSW production and supply to agriculture are a key issue when planning its implementation at regional scale.

Specific energy consumption $\left(\mathrm{SEC}, \mathrm{kW} / \mathrm{m}^{3}\right.$ ) is a common measure of the energy use in desalination processes [38]. A typical DSW production and supply system for agriculture in SE Spain consists of five stages, each with different SEC requirements, as represented in Figure 4: (1) seawater intake pumping; (2) desalination processes; (3) pumping to a regulating elevated reservoir; (4) gravity-driven conveyance to irrigation districts; and (5) pumping for water distribution within irrigation districts themselves. Table 2 shows the SEC values for these stages at seven SWDPs in SE Spain, whilst the variation range at each stage is depicted in Figure 4. 
Table 2. Specific energy consumption for the different stages (Figure 4) of DSW production and supply to irrigated agriculture in 2017. All values refer to DSW volume.

\begin{tabular}{|c|c|c|c|c|c|c|}
\hline \multirow{2}{*}{$\begin{array}{l}\text { Desalination Plant } \\
\text { (SWDP) }\end{array}$} & (1) & (2) & $(3)+(4)$ & (5) & \multirow{2}{*}{$\begin{array}{c}\text { Total } \\
\left(\mathbf{k W h} / \mathbf{m}^{3}\right)\end{array}$} & \multirow[b]{2}{*}{ Data from } \\
\hline & $\begin{array}{l}\text { Seawater Intake } \\
\left(\mathrm{kWh} / \mathrm{m}^{3}\right)\end{array}$ & $\begin{array}{c}\text { Desalination } \\
\text { Processes }\left(\mathrm{kWh} / \mathrm{m}^{3}\right)\end{array}$ & $\begin{array}{l}\text { DSW Pumping to Irrigation } \\
\text { Districts }\left(\mathrm{kWh} / \mathrm{m}^{3}\right)\end{array}$ & $\begin{array}{c}\text { DSW Distribution in Irrigation } \\
\text { Districts }\left(\mathrm{kWh} / \mathrm{m}^{3}\right)\end{array}$ & & \\
\hline Mazarrón & 0.42 & 3.06 & 1.00 & 0 (gravity-driven distribution) & 4.48 & Questionnaire \\
\hline La Marina & 0.20 & 3.20 & 0.70 & 0 (gravity-driven distribution) & 4.10 & Questionnaire \\
\hline Escombreras & 0.40 & 3.35 & 0.75 & 0 (gravity-driven distribution) & 4.50 & Questionnaire \\
\hline $\begin{array}{l}\text { Average value for } \\
\text { Private SWDPs }\end{array}$ & - & - & - & - & 4.36 & - \\
\hline Valdelentisco * & 0.36 & 3.24 & 0.92 & 0 (gravity-driven distribution) & 4.52 & Questionnaire, [31] and [39] \\
\hline Águilas-Guadalentín & 0.37 & 2.85 & 1.04 & 0.20 & 4.46 & Questionnaire, [31] and [39] \\
\hline Torrevieja & 0.12 & 2.78 & 0.43 & 0.16 & 3.49 & Questionnaire, [31] and [39] \\
\hline Carboneras ** & 0.62 & 3.38 & 0.84 & 0 (gravity-driven distribution) & 4.84 & Questionnaire, [31] and [39] \\
\hline $\begin{array}{l}\text { Average value for } \\
\text { Public SWDPs }\end{array}$ & - & - & - & - & 4.32 & - \\
\hline
\end{tabular}

* There were nine reverse osmosis frames with Pelton turbines and two frames with isobaric pressure-exchangers as energy recovery system in 2017. ${ }^{* *}$ There were ten reverse osmosis frames with Pelton turbines and two frames with isobaric pressure-exchangers as energy recovery system in 2017. 
In the first stage, seawater is pumped to the SWDP, with an SEC that ranges from 0.12 to $0.62 \mathrm{kWh} / \mathrm{m}^{3}$ of DSW, depending mainly on the altitude of the SWDP above sea level. Then, several processes (pretreatments, reverse osmosis, and post-treatments) are carried out in the industrial facility to produce DSW, with an SEC that ranges from 2.78 to $3.35 \mathrm{kWh} / \mathrm{m}^{3}$ of DSW. The consumption in this stage is related to several technical factors, such as the salinity of the feed water, the targeted DSW quality, the capacity of the plant, the use of energy recovery systems and the type of membrane technology, among others [37,40]. It should be noted that brine disposal at sea is carried out using the brine residual pressure after reverse osmosis process and taking advantage of the slope, so no additional SEC is required. Once DSW is produced, it is stored in an elevated reservoir for regulation, which requires a pumping system consuming between 0.43 and $1.03 \mathrm{kWh} / \mathrm{m}^{3}$. After that, DSW is gravity-conveyed and distributed to irrigation districts or individual farmers, without additional SEC for all the cases studied. For most SWDPs, the consumers are several irrigation districts (or only one for the private SWDPs), but some of them (Escombreras and Valdelentisco SWDPs) have their own distribution pipe systems with irrigation hydrants for supplying farmers directly. When DSW is finally allocated through the irrigation district infrastructure, an additional SEC ranging from 0 to $0.20 \mathrm{kWh} / \mathrm{m}^{3}$ of DSW is required in their pumping facilities.

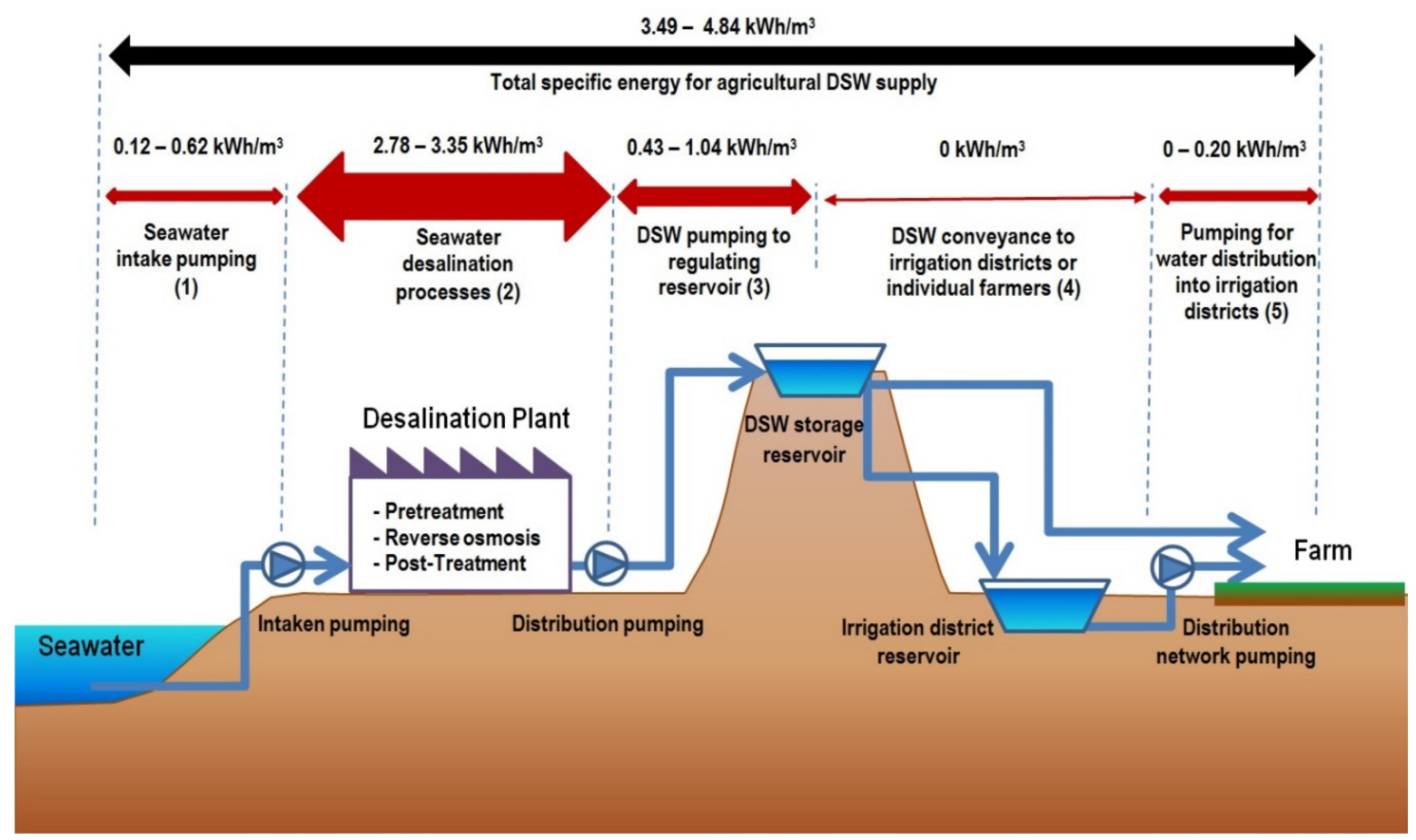

Figure 4. Characteristic values of specific energy consumption $\left(\mathrm{kW} / \mathrm{m}^{3}\right)$ for the different stages of DSW production and supply for irrigation in SE Spain in 2017.

Adding up all stages, it is noteworthy that the mean value of total SEC for the private SWDPs $\left(4.36 \mathrm{kWh} / \mathrm{m}^{3}\right)$ is similar to that of the public SWDPs $\left(4.32 \mathrm{kWh} / \mathrm{m}^{3}\right)$, as shown in Table 2, and with a similar stage distribution. These figures evidence that both initiatives for agricultural DSW supply (public and private) have similar results from an SEC perspective.

The mean SEC for seawater retrieval and DSW allocation (stages 1, 3, 4, and 5) amounts to $1.22 \mathrm{kWh} / \mathrm{m}^{3}$ of DSW, which represents $28.1 \%$ of the mean total SEC $\left(4.34 \mathrm{kWh} / \mathrm{m}^{3}\right)$. Conveyance and distribution pumping from the SWDPs to farms (stages 3, 4, and 5) can consume from 0.59 to $1.24 \mathrm{kWh} / \mathrm{m}^{3}$, depending on the altitude of the farm above the SWDP and the distance inland, which is also a substantial portion of the mean total SEC (19.9\%). This figure highlights that it is also important to consider energy saving technologies in the design of conveyance and distribution systems for DSW [41]. 
Focusing on DSW production (stage 2), the SEC ranges from 2.85 to $3.38 \mathrm{kWh} / \mathrm{m}^{3}$, which is in the very lowest part of the range reported by Shaffer et al. [37] for state-of-the-art DSW production in 2012 $\left(3-7 \mathrm{kWh} / \mathrm{m}^{3}\right)$. This result seems reasonable since all considered SWDPs have a large capacity and where built or updated with isobaric energy recovery devices in recent years. Zarzo and Prats [42] reported in 2018 a new SEC range of $2.5-4 \mathrm{kWh} / \mathrm{m}^{3}$ for large SWDPs (30-100 $\mathrm{Mm}^{3} / \mathrm{year}$ ), which fits very well with the obtained results. As mentioned above, the SEC in this stage is related to several technical factors. Figure 5 analyzes some of these factors considering the data from seven SWDPs in the study area, such as the age of the plant (Figure 5A), the production capacity (Figure 5B), and the energy recovery systems in the reverse osmosis racks (Figure 5C).

For Spanish SWDPs, the decrease of SEC in recent years has been significant, dropping from an average of $8.5 \mathrm{kWh} / \mathrm{m}^{3}$ in 1990 to $<3 \mathrm{kWh} / \mathrm{m}^{3}$ in 2009 [43]. This reduction was mainly due to the inclusion of new energy recovery devices, such as Francis or Pelton turbines, and more recently isobaric devices [42]. Figure 5A shows how the decreasing trend of SEC in the SWDPs supplying agriculture in SE Spain continues. The Águilas-Guadalentín and Torrevieja plants, which started up in 2013 and 2014 respectively, have SEC values below $3 \mathrm{kWh} / \mathrm{m}^{3}$, whereas the remaining SWDPs, which started up before 2010 have SEC values over $3 \mathrm{kWh} / \mathrm{m}^{3}$, in spite of the incorporation of isobaric recovery devices in recent years. The regression analysis with a linear function indicated a low correlation $\left(R^{2}=0.21, p<0.05\right)$ but, if Mazarrón SWDP is suppressed, the correlation increases significantly $\left(R^{2}=0.83, p<0.05\right)$. This abnormal behavior of Mazarrón SWDP can be explained by the fact that water is withdrawn with vertical coastal soundings in an aquifer with seawater intrusion, resulting in an electrical conductivity of $50 \mathrm{dS} / \mathrm{m}$ in raw water, whereas the remaining SWDPs have open sea intakes with raw water electric conductivity around $55 \mathrm{dS} / \mathrm{m}$.

Reverse osmosis SWDPs with larger treatment capacities often have economies of scale in terms of SEC due to efficiency gains associated with larger pumps, which can reach an efficiency of about $90 \%$ when combined with energy recovery devices [44]. Figure 5B shows a clear effect of SWDP size on SEC in the facilities studied, which is well correlated by a regression analysis with a linear function $\left(R^{2}=0.49, p<0.05\right)$. Again, when Mazarrón SWDP was suppressed, the correlation increased $\left(\mathrm{R}^{2}=0.62, p<0.05\right)$.

Figure 5C focuses on the SEC in the reverse osmosis racks. The theoretical minimum SEC was calculated based on thermodynamic constraints at approximately $1.06 \mathrm{kWh} / \mathrm{m}^{3}$ for incoming raw water with total dissolved solids concentration of $35,000 \mathrm{mg} / \mathrm{L}$ at $50 \%$ recovery [5]. Real consumption is higher and also depends on other factors, such as operating conditions, temperature, recovery rate, etc. [45]. Taking into account that real SWDPs are not an ideal system, the observed values for larger and more modern SWDPs (2.2-2.3 kWh/m ${ }^{3}$ in Águilas-Guadalentín and Torrevieja SWDPs) are currently close to the thermodynamic limit, which implies that it is becoming increasingly difficult to reduce SEC in reverse osmosis technologies below their current values [42]. Figure 5C reveals a clear difference in the performance of public and private facilities. Public SWDPs present a mean SEC of $2.27 \mathrm{kWh} / \mathrm{m}^{3}$ in reverse osmosis racks, which is $0.57 \mathrm{kWh} / \mathrm{m}^{3}$ lower than the mean value for private SWDPs $\left(2.84 \mathrm{kWh} / \mathrm{m}^{3}\right)$, despite the fact that all the racks compared have isobaric recovery devices. Therefore, this result evidences that there is a clear age and scale effect in the SEC at the racks, since private SWDPs are usually older and smaller than public ones (Table 1). However, this difference decreases when considering SEC in the whole DSW production process (stage 2, Table 2) because the pretreatments and post-treatment processes are minimized in private SWDPs supplying agriculture exclusively. This minimization is possible since they do not have to comply with potable water regulations [6], and post-treatments are usually replaced by water blending with highly mineralized groundwater. 
A. Specific energy in desalination processes vs SWDP age

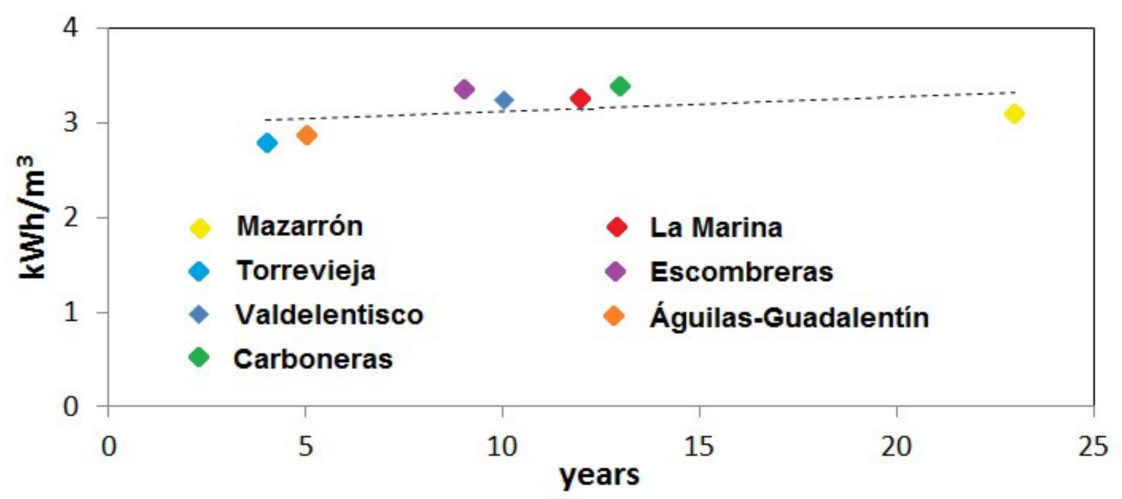

\section{B. Specific energy in desalination processes vs SWDP size}
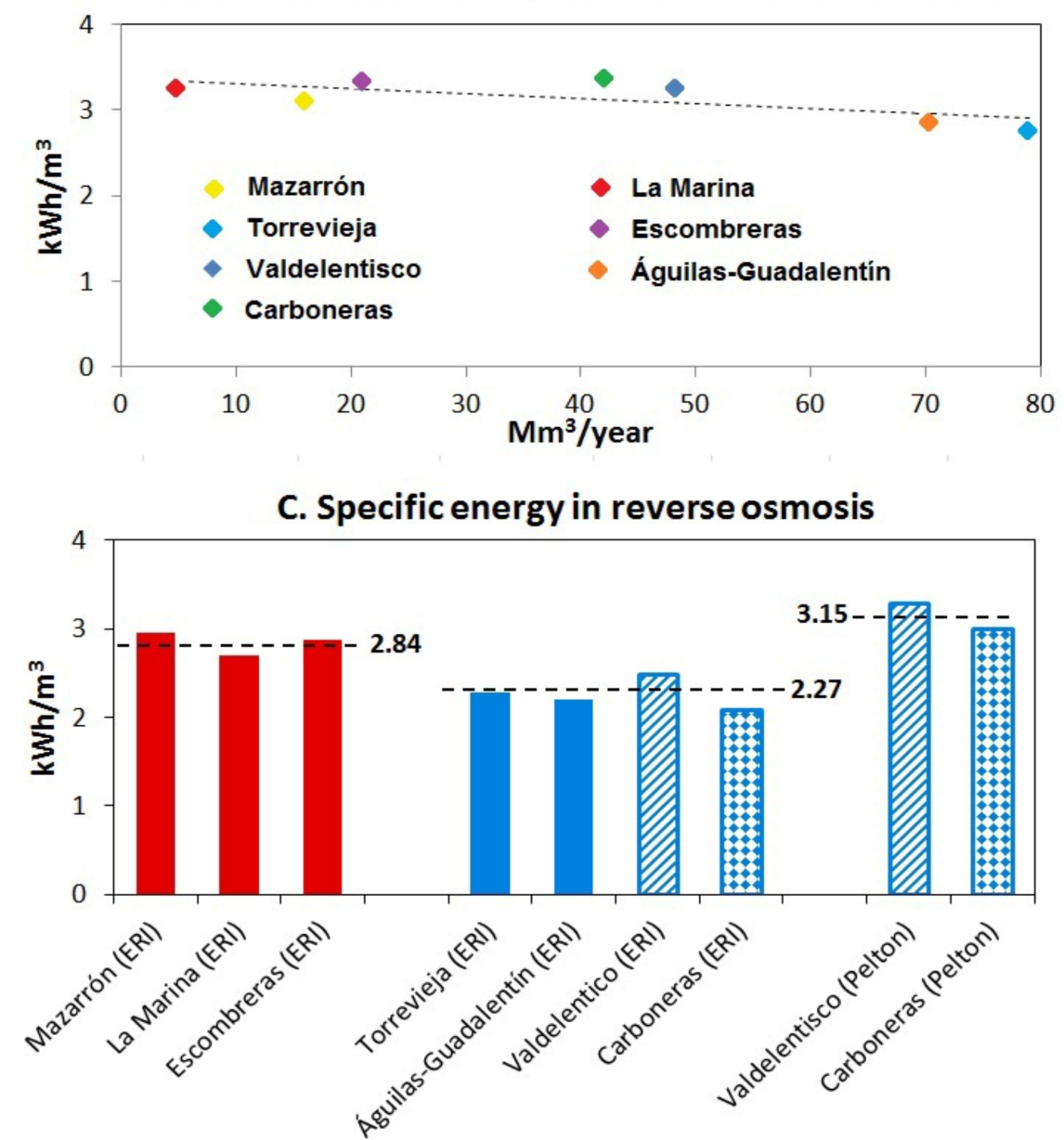

Figure 5. Effect of the age of the plant (A), the production capacity (B), and the energy recovery systems (C) on the specific energy consumption of DSW production (stage 2). Private and public SWDPs are shown in blue and red in C, respectively. The bar patterns in C indicate racks with different energy recovery (isobaric recovery devices (ERI) or Pelton turbines) in Valdelentisco and Carboneras SWDPs.

The use of energy recovery technologies can substantially reduce the SEC in desalination racks $[46,47]$. In seawater reverse osmosis, Pelton turbines typically provide energy savings of $35 \%$ to $42 \%$ compared to a baseline without energy recovery equipment, while the saving values for isobaric recovery systems range from $55 \%$ to $60 \%$ [48]. The influence of the implemented energy recovery technology on SEC is clear in Figure 5C for Valdelentisco and Carboneras SWDPs, which had some 
reverse osmosis racks equipped with Pelton turbines and others with isobaric recovery systems during 2017, since they are involved in an upgrade process to optimize the rack configuration and improve the energy efficiency of the facility. The SEC reduction after the upgrade process reached $0.8 \mathrm{kWh} / \mathrm{m}^{3}$ in Valdelentisco and $0.9 \mathrm{kWh} / \mathrm{m}^{3}$ in Carboneras, leading to the anecdotal data that the most efficient rack in operation to date in SE Spain is located in an SWDP started up in 2005 (the oldest public one).

\subsection{Costs of DSW Supply to Agriculture}

Following the supply structure depicted in Figure 4, the total cost of DSW for agricultural in SE Spain can be divided into three components: the amortization and financial costs, the operational and maintenance (O\&M) costs for production, and the costs for allocation.

The amortization and financial costs correspond to the initial investment (acquisition of land, construction, seawater intake facilities, submarine brine discharge facilities, DSW regulation and conveyance facilities, etc.) which extend across the lifespan of the SWDP. When managed as specific costs $\left(€ / \mathrm{m}^{3}\right)$, they can be considered as dynamic since they depend on: (1) the considered lifespan of the project, (2) the variable interest rate that usually operates in the financial plan, and (3) the production rate, which is generally assumed to be the projected capacity throughout the lifespan, although this was not the real case in SE Spain [49].

The O\&M costs for DSW production (energy consumption, pretreatment and post-treatment, labor, taxes, maintenance, etc.) correspond to all the operational period and markedly depend on energy consumption, which usually represents around 50\%-60\% of O\&M costs $[27,40,50]$. For that reason, there is a direct relationship between energy consumption and the operational costs that is adjusted by the energy price [51], which also makes specific O\&M costs $\left(€ / \mathrm{m}^{3}\right)$ dynamic. The fluctuation in the energy costs was important in Spain, with electricity prices rising from $0.08 € / \mathrm{kWh}$ in 2008 to $0.14 € / \mathrm{kWh}$ in 2012 , leading to an increase in total DSW total costs from $0.32-0.36 € / \mathrm{m}^{3}$ (in 2008) to $0.56-0.63 € / \mathrm{m}^{3}$ (in 2012) [27,50].

Finally, there are two types of costs for DSW allocation from SWDPs to farms: (1) the cost of water conveyance from SWDPs to the irrigation districts, which is usually done by pipelines and ponds systems belonging to SWDPs; and (2) the distribution cost into the irrigation districts, which is added to the management and operating costs in the final price of water supplied to farmers. The former is typically a cost in the DSW supply from public SWDPs, which are usually located away from irrigation districts. This cost usually does not exist in private SWDPs, which are located in the owner's irrigation district. The latter cost is site specific, and can be close to zero for irrigation districts that have gravity-driven distribution systems, and nearly $0.1 € / \mathrm{m}^{3}$ for districts with high pumping requirements in their distribution systems. The total of both costs together is also dynamic since they are mainly dependent on the energy consumption.

As a result of the dynamism of all three components of the total cost for DSW agricultural supply, very variable figures have been reported for their values in Spain [27,50,52]. Table 3 shows the values of each component and the total cost for two private SWDPs (Mazarrón and La Marina) and two public ones (Valdelentisco and Águilas-Guadalentín) in 2017. The average total specific costs for private and public SWDPs are 0.70 and $0.55 € / \mathrm{m}^{3}$, respectively. The difference of $0.15 € / \mathrm{m}^{3}$ is mainly due to the amortization and financial costs, which are currently calculated by the owner companies, considering a 25-year lifespan for private SWDPs and 50 years for the public ones. This difference almost completely disappears if the amortization and financial costs in the public SWDPs were calculated considering a 25-year lifespan. According to Lapuente [52], these costs would be 0.26 and $0.22 € / \mathrm{m}^{3}$ in the Valdelentisco and Águilas-Guadalentín SWDPs, respectively, for a 25-year lifespan, rather than the $0.10 € / \mathrm{m}^{3}$ shown in Table 3 for a 50-year lifespan, resulting in an average total specific cost of $0.69 € / \mathrm{m}^{3}$. Therefore, under the same lifespan assumptions, both initiatives for agricultural DSW supply (public and private) have similar results from a total specific cost perspective. 
Table 3. Costs of DSW production and supply to irrigated agriculture in 2017 in several SWDPs. Production rate is considered to be $80 \%$ of maximum capacity.

\begin{tabular}{|c|c|c|c|c|c|c|c|}
\hline \multirow{2}{*}{$\begin{array}{l}\text { Desalination } \\
\text { Plant (SWDP) }\end{array}$} & \multirow{2}{*}{$\begin{array}{c}\text { Amortization and } \\
\text { Financial Costs } \\
\left(€ / \mathrm{m}^{3}\right)^{*}\end{array}$} & \multicolumn{2}{|c|}{$\begin{array}{c}\text { Operation and Maintenance } \\
\text { Costs }\left(€ / \mathrm{m}^{3}\right)\end{array}$} & \multirow{2}{*}{$\begin{array}{l}\text { Distribution to } \\
\text { Irrigation } \\
\text { Districts }\left(\boldsymbol{\epsilon} / \mathrm{m}^{3}\right)\end{array}$} & \multirow{2}{*}{$\begin{array}{c}\text { Distribution } \\
\text { within Irrigation } \\
\text { Districts }\left(€ / \mathbf{m}^{3}\right)\end{array}$} & \multirow{2}{*}{$\begin{array}{l}\text { Total } \\
\left(€ / \mathrm{m}^{3}\right)\end{array}$} & \multirow{2}{*}{ Data from } \\
\hline & & Energy & Other O\&M & & & & \\
\hline Mazarrón & 0.20 & 0.29 & 0.11 & - & 0.08 & 0.68 & Questionnaire \\
\hline La Marina & 0.22 & 0.32 & 0.08 & - & 0.09 & 0.72 & Questionnaire \\
\hline $\begin{array}{l}\text { Average value for } \\
\text { Private SWDPs }\end{array}$ & - & - & - & - & - & 0.70 & - \\
\hline Valdelentisco & 0.10 & 0.29 & 0.09 & 0.09 & - & 0.57 & Questionnaire and adapted from [30] \\
\hline Águilas-Guadalentín & 0.10 & 0.22 & 0.09 & 0.08 & 0.04 & 0.53 & Questionnaire and adapted from [30] \\
\hline $\begin{array}{l}\text { Average value for } \\
\text { Public SWDPs }\end{array}$ & - & - & - & - & - & 0.55 & - \\
\hline
\end{tabular}

* Amortization and financial costs refer to a 25-year lifespan in Mazarrón and La Marina, and to a 50-year lifespan in Valdelentisco and Águilas-Guadalentín. 
The variation range of the total costs in Table 3 (from 0.53 to $0.72 € / \mathrm{m}^{3}$ ) is similar to that reported for Israeli large-scale SWDPs supplying agriculture (from 0.50 to $0.66 € / \mathrm{m}^{3}$, adapted from [53]). The slight difference can be explained because the values reported for Israel do not include the distribution costs to the irrigation districts. When these costs are suppressed, the variation range for Spanish SWDPs (from 0.49 to $0.63 € / \mathrm{m}^{3}$ ) matches the range for Israel. This similarity in total costs was to be expected since both countries developed their desalination programs in similar periods and using the same technological approach.

Figure 6 depicts the share of costs for three of the SWDPs included in Table 4, differentiating between energy costs and other O\&M costs. Both public SWDPs, Valdelentisco (Figure 6A) and Águilas-Guadalentín (Figure 6B) present very similar results: amortization and financial costs range from $18 \%$ to $21 \%$, allocation costs represent $16 \%$ for both plants, and O\&M costs range from $63 \%$ to $66 \%$ of total costs. It should be noted that the energy costs amount to $77.2 \%$ and $69.8 \%$ of O\&M costs for Valdelentisco and Águilas-Guadalentín SWDPs, respectively; values which are above the range of $50 \%-60 \%$ previously reported by other authors in Spain $[27,50]$. The share of costs for the private SWDP of La Marina shows a different pattern due to the different lifespan considered in the calculation of the amortization and financial costs, as mentioned above. In this case, the energy costs amounted to $80.4 \%$ of O\&M costs, once again a value above those previously reported.

A. Share of costs in Valdelentisco SWDP in 2017

- Amortization and financial costs $=0 \& \mathrm{M}$ costs $\|$ Distribution costs - Energy costs $=$ Other O\&M costs

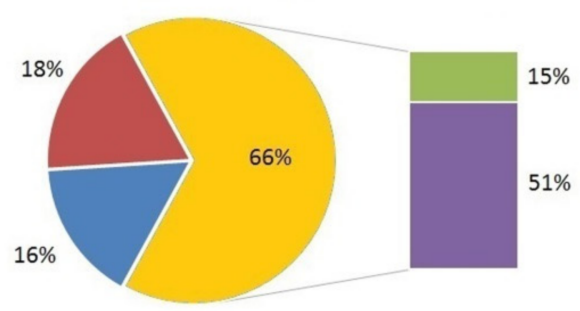

C. Share of costs in La Marina SWDP in 2017

- Amortization and financial costs $=0 \& \mathrm{M}$ costs $\quad$ - Distribution costs - Energy costs $\quad$ Other O\&M costs

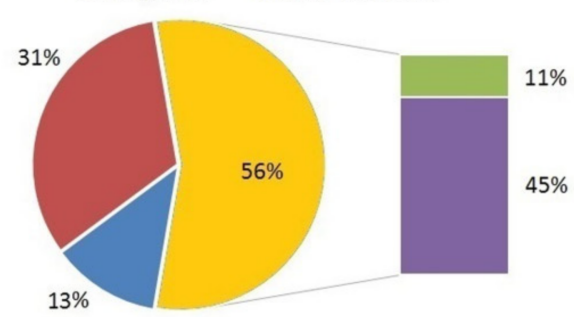

B. Share of costs in Águilas-Giadalentín SWDP in 2017

- Amortization and financial costs $=0 \& \mathrm{M}$ costs $\|$ Distribution costs = Energy costs $=$ Other O\&M costs

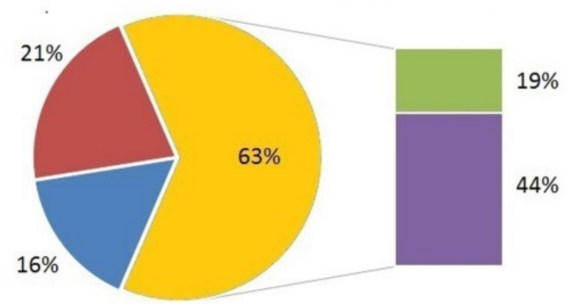

D. Variation in costs with production rate in Águilas Guadalentín SWDP

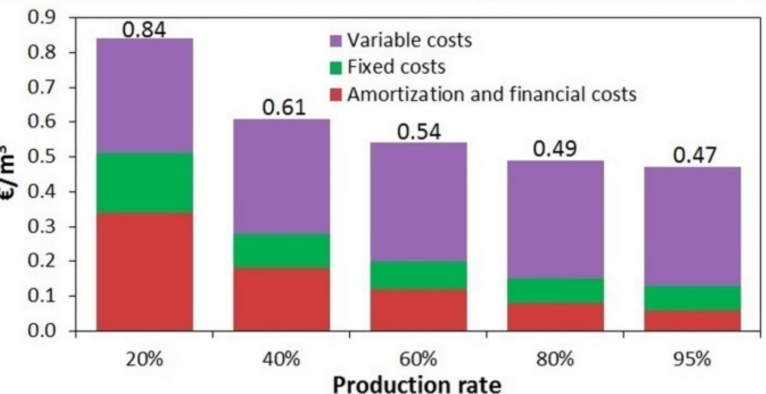

Figure 6. Share of costs in Valdelentisco SWDP (A), in Águilas-Guadalentín SWDP (B), and in La Marina SWDP (C). Subfigure (D) represents the variation in costs in Águilas-Guadalentín SWDP with respect to the production rate. 
Table 4. Composition and final price of water supplied to farmers from each SWDP in 2017.

\begin{tabular}{|c|c|c|c|c|c|c|}
\hline $\begin{array}{l}\text { Desalination } \\
\text { Plant (SWDP) }\end{array}$ & $\begin{array}{l}\text { Production Price } \\
\qquad\left(€ / \mathrm{m}^{3}\right)\end{array}$ & $\begin{array}{l}\text { 10\% Taxes } \\
\left(€ / \mathrm{m}^{3}\right)\end{array}$ & $\begin{array}{c}\text { Conveyance to } \\
\text { Irrigation Districts } \\
\left(€ / \mathbf{m}^{3}\right)\end{array}$ & $\begin{array}{l}\text { Distribution within } \\
\text { Irrigation Districts } \\
\left(€ / \mathrm{m}^{3}\right)\end{array}$ & $\begin{array}{l}\text { Final Price to } \\
\text { Farmers } \\
\left(€ / \mathrm{m}^{3}\right)\end{array}$ & Comments \\
\hline $\begin{array}{l}\text { Mazarrón } \\
\text { (Virgen del Milagro) }\end{array}$ & 0.40 & - & - & 0.08 & 0.48 & $\begin{array}{l}\text { The SWDP is located in the irrigation district. } \\
\text { Amortization and financial costs were subsidized. }\end{array}$ \\
\hline La Marina & 0.62 & - & - & 0.09 & 0.47 & $\begin{array}{c}\text { The SWDP is located in the irrigation district. } \\
\text { Final price is lower than DSW price since it is } \\
\text { blended with brackish groundwater before } \\
\text { supplying farmers. }\end{array}$ \\
\hline Escombreras & 0.5 & 0.05 & 0.02 & 0.03 & 0.60 & $\begin{array}{l}\text { The SWDP is located far from the irrigation } \\
\text { district. This SWDP also supplies directly to some } \\
\text { farmers with its own } \\
\text { conveyance/distribution network. }\end{array}$ \\
\hline $\begin{array}{l}\text { Average value for } \\
\text { Private SWDPs }\end{array}$ & - & - & - & - & 0.52 & - \\
\hline Valdelentisco & 0.57 & 0.06 & * & * & 0.63 & $\begin{array}{l}\text { The SWDP is located far from the irrigation } \\
\text { district, but it has a conveyance/distribution } \\
\text { network with on-farm hydrants. }\end{array}$ \\
\hline Águilas-Guadalentín & 0.42 & 0.04 & * & 0.04 & 0.50 & $\begin{array}{l}\text { The SWDP is located far from the irrigation } \\
\text { district. The price in supply contracts ranges from } \\
0.38 \text { to } 0.50 \text {, with } 0.42 \text { being the average value. }\end{array}$ \\
\hline Torrevieja & 0.49 & 0.05 & 0.02 & 0.03 & 0.59 & $\begin{array}{l}\text { The SWDP is located far from the irrigation } \\
\text { district and only supplies to irrigation districts. }\end{array}$ \\
\hline Carboneras & 0.49 & 0.05 & * & 0.02 & 0.55 & $\begin{array}{l}\text { The SWDP is located far from the irrigation } \\
\text { district. DSW is gravity-driven distributed into } \\
\text { the irrigation district. }\end{array}$ \\
\hline Campo de Dalías & 0.5 & 0.05 & * & 0.03 & 0.58 & The SWDP is located in the irrigation district. \\
\hline $\begin{array}{l}\text { Average value for } \\
\text { Public SWDPs }\end{array}$ & - & - & - & - & 0.55 & - \\
\hline
\end{tabular}

* This item is included in the SWDP production price. Data from questionnaires. 
Figure 6D depicts the effect of the production rate on the share of costs of Águilas-Guadalentín SWDP in 2017, distinguishing among amortization and financial costs, variable costs and fixed costs, following the data by ACUAMED [30]. The analysis shows the relevance of the production rate on the total cost of DSW production, which significantly increases when the rate is below $60 \%$. Therefore, maintaining DSW production close to the projected capacity throughout their lifespan is essential to enable compliance with the expected costs. This was not the case in SE Spain for the relatively wet period 2010-2014, when agricultural DSW demand fell due to the abundance of cheaper alternative supplies and, consequently, SWDPs consistently operated below their planned capacity and above the expected costs [49]. To control and stabilize agricultural DSW demand, long term take-or-pay contracts between SWDPs and irrigation districts should be signed, in a similar way to what has been done in Israel, where a take-or-pay policy ensures that the government will pay for the agreed volume of water supplied by SWDPs each year, hence guaranteeing that the facilities operate at their projected capacity [10].

Figure $6 \mathrm{D}$ also reveals how the share of variable costs with respect to the total cost decreases when the DSW production rate decreases. Taking into account that energy consumption is by far the highest variable cost, this behavior can explain why energy costs in the present study amount to a higher proportion of O\&M costs (70\%-80\%) than that previously reported in Spain $(50 \%-60 \%)$, since the data managed by previous studies correspond to a period (2010-2014) when DSWPs were operating at a lower rate (around 50\%) than in 2017 (around 80\%).

\subsection{Price of DSW Supply to Farmers}

The price that farmers actually pay for DSW and which affects their farming costs is composed of (1) the production price at the SWDP; $(2)$ a consumption tax (VAT $=10 \%)$ that operates whenever the consumer is different from the DSW producer and supplying implies a commercial transaction; (3) a transfer toll whenever conveyance to irrigation systems uses infrastructures other than those owned by the SWDPs or irrigation districts; and (4) the irrigation district rate, which passes on all their costs in the final price of supplied water to farmers. Table 4 displays each price component and the resulting final price for the same SWDPs shown in Table 2.

The final price of DSW supply to farmers ranges from $0.48 € / \mathrm{m}^{3}$ in the Mazarrón SWDP to $0.63 € / \mathrm{m}^{3}$ in the Valdelentisco SWDP, with an average value for private SWDPs $\left(0.52 € / \mathrm{m}^{3}\right) 6.5 \%$ below the average value for public SWDPs $\left(0.55 € / \mathrm{m}^{3}\right)$. This result is contradictory with the total supply costs obtained in Table 3, where the cost for private SWDPs $\left(0.70 € / \mathrm{m}^{3}\right)$ was higher than that of the public ones $\left(0.55 € / \mathrm{m}^{3}\right)$, and hence additional analysis is necessary. First, the average final supply price to farmers from public SWDPs $\left(0.55 € / \mathrm{m}^{3}\right)$ matches their average total cost $\left(0.55 € / \mathrm{m}^{3}\right)$, as would be expected in a non-for-profit system where only public companies or corporations (irrigation districts) operate. Therefore, the contradiction lies in the supply price to farmers from private SWDPs, which is caused by different reasons for Mazarrón and La Marina. In Mazarrón SWDP, the initial investment was subsidized with public funds, so the amortization and financial costs $\left(0.20 € / \mathrm{m}^{3}\right)$ are not charged in the final price to farmers. In La Marina SWDP, DSW is blended with cheaper groundwater as a remineralization post-treatment, resulting in a final price to farmers well below the DSW production price (Table 4 ).

The aforementioned DSW prices are much higher than other agricultural supplies in SE Spain, as shown in Figure 7. Such a difference implies that, if traditional agricultural water sources are systematically replaced with DSW under the increased pressure on conventional water resources, the profitability of all crops would be seriously reduced, and some would even become economically unsustainable [10]. For that reason, farmers have systematically been unwilling to pay the total DSW costs over the last years, and regularly call on the government to subsidize agricultural DSW use [7]. In such a way, direct subsidies were sanctioned by the Spanish Government in 2016 and 2017, as an extraordinary measure to mitigate the effects of the water shortage on the T-S aqueduct supply. These subsidies consisted in discounts of $0.2 € / \mathrm{m}^{3}$ for $30 \mathrm{Mm}^{3}$ supplied from the Torrevieja SWDP and 
$0.1 € / \mathrm{m}^{3}$ for $20 \mathrm{Mm}^{3}$ supplied from the Valdelentisco SWDP. In total, the direct subsidy represented $8 \mathrm{M} €$ each year, and undoubtedly contributed to the increase in DSW demand for crop irrigation in 2016-2017. This subsidy reflects the socio-economic strategic role of irrigated agriculture in SE of Spain, where the overall societal benefits can balance out subsidies over time.

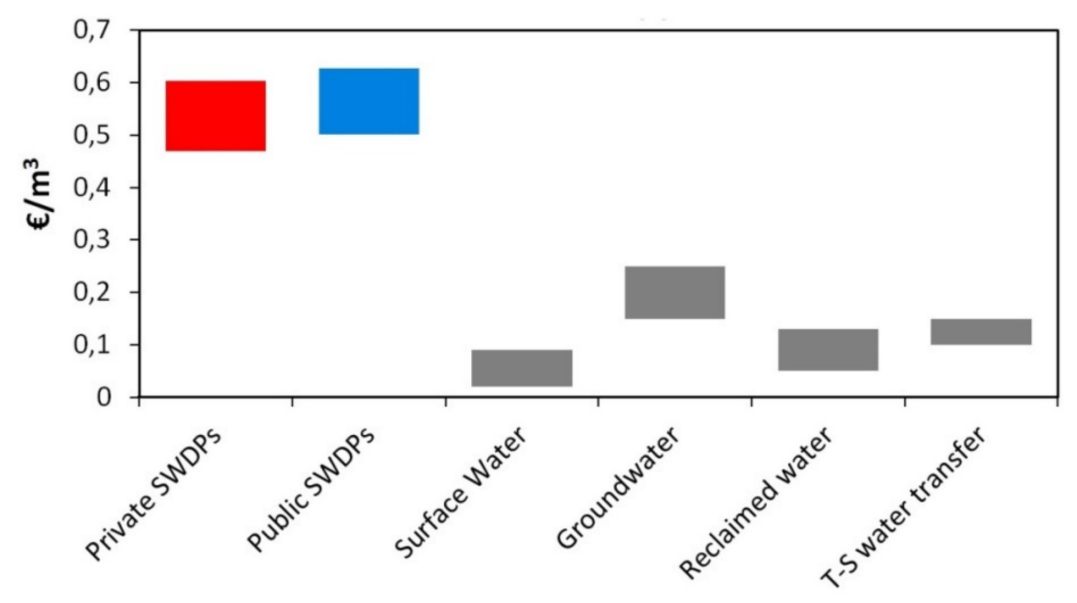

Figure 7. Price of agricultural water supply from different sources in the study area, including DSW from private and public SWDPs. Data obtained from questionnaires and own data.

The current unceasing agricultural demand for DSW (Figure 2) could be interpreted as evidence that agriculture is able to withstand water prices of about $0.50-0.60 € / \mathrm{m}^{3}$, yet the analysis by [6] clarified that the increased farming costs of incorporating DSW lessen the mean net marginal value of water close to zero in many agricultural regions of SE Spain. This implies that the systematic replacement of traditional water sources with DSW is not a general solution to water scarcity in the agriculture of this region. Moreover, the interviews with irrigation district managers brought to light the importance of the availability of other water resources with lower prices to perform water blending strategies leading to final irrigation water prices of about $0.30-0.35 € / \mathrm{m}^{3}$, which seem affordable for a wide range of crops. For that reason, DSW is currently considered as a complementary source for crop irrigation in SE Spain, and water blending is the most recommended management practice. In fact, in addition to counterbalancing high costs, it can mitigate the most relevant agronomical concerns related to the singular chemical composition of DSW $[11,15,54]$. Therefore, agronomic and economic issues highlight the benefits of an integrated planning and management of DSW and other available water resources in each irrigation district.

\section{Conclusions}

Food security concerns, climate change impacts and increased pressure on conventional water resources are encouraging the agricultural use of DSW. Here, we present the case of SE Spain as an example of how the integration of DWS for irrigation can strengthen the resilience of high-return agriculture. However, incorporating DSW into irrigation water planning in coastal areas facing persistent water scarcity is a complex and long process. To assess its feasibility several technical, economic, societal and environmental factors must be overlaid. Based on the case presented here, it is recommended that DWS is considered as a base supply in regional water planning and management instead of an emergency supply for accommodating shortfalls in demand. The reason for this is that SWDPs should operate at close to their projected capacity throughout their lifespan to comply with the expected costs. The agricultural demand of DWS in SE Spain has fluctuated remarkably as a response to the varying availability of traditional water resources. It is no surprise that in wet periods, when cheaper resources were available, farmers used them and the demand for DSW plummeted, leaving desalination plants underutilized. In this sense, in order to ensure the successful integration of DSW into regional agricultural water planning, take-or-pay contracts between SWDPs and irrigation districts 
or governmental institutions could be a suitable option to enable the long-term economic sustainability of SWDPs.

Another major constraint for DSW integration identified here is the location of SWDPs at the coast. Traditional irrigation water supply systems in SE Spain are designed to deliver water from inland to the coastline, taking advantage of the slope, so they cannot deal with the delivery of DSW from the coast to inland. Therefore, supplying DSW to inland agriculture would involve the construction of long conveyance pipelines and additional energy requirements for pumping against hydraulic heads, and hence the increase of the total DSW supply costs. For this reason, the current agricultural use of DSW in SE Spain takes places in coastal areas and their surroundings, which stresses the need to account for the investment costs of new water distribution systems when planning any inland allocation of DSW.

One of the main barriers to the widespread use of DSW for irrigation is its higher total cost in relation to other traditional water sources. The high price of DSW (from 0.53 to $0.72 € / \mathrm{m}^{3}$ ) is the consequence of the vast amounts of energy required for production and distribution. The total SEC ranges from 3.49 to $4.84 \mathrm{kWh} / \mathrm{m}^{3}$, of which roughly $70 \%$ is consumed in the desalination processes, whereas the remaining 30\% corresponds mainly to DSW allocation and distribution. However, it must be highlighted that DSW plays a complementary role in most irrigation districts, where it is usually managed along with other conventional water resources. This makes using DSW economically affordable and it might additionally minimize the main agronomic concerns highlighted in other studies (lack of essential nutrients, high presence of phytotoxic ions and soil alkalinization) $[6,11,14]$.

When discriminating between private and public SWDPs, the specific energy consumption and general costs are very similar, which indicates that both initiatives for agricultural DSW supply perform similarly. The final supply price to farmers exactly matches the total costs in public SWDPs, as would be expected from a non-for-profit system. However, this is not the case for private SWDPs, where the existence of subsidies or other management practices (water blending) usually reduce the final supply prices to farmers.

Overall, notwithstanding the high cost of DSW, its agricultural use can foster irrigated agriculture resilience as water scarcity intensifies in a changing climate, helping to preserve socioeconomic development in highly profitable agricultural areas, where no other water resources and/or economic activity alternatives are possible.

Author Contributions: The article was written by V.M.-A., with the rest of the authors (J.F.M.-V., M.J.G.-O., B.G.-E., and B.M.-G.) providing many valuable comments. All authors have equally contributed to the methodology implementation, data acquisition, data analysis, and derived conclusions. All authors have revised and approved the final manuscript.

Funding: This study was supported by the European Regional Development Fund (ERDF) and Ministerio de Ciencia, Innovación y Universidades-Agencia Estatal de Investigación (Grant number AGL2017-85857-C2-2-R), and by the European Commission (Grant LIFE16 ENV/ES/000341, DESEACROP Project).

Acknowledgments: The authors would like to thank all the desalination plants and the irrigation district managers for providing the data on which the study has been carried out. The collaboration of partners in DESEACROP Project (Universidad de Almería, Valoriza Agua, and Comunidad de Usuarios de Aguas de la Comarca de Nijar) is also acknowledged.

Conflicts of Interest: The authors declare no conflict of interest.

\section{References}

1. United Nations Educational, Scientific and Cultural Organization (UNESCO). The 3rd United Nations World Water Development Report: Water in a Changing World; UNESCO: Paris, France, 2009; 318p.

2. Intergovernmental Panel on Climate Change (IPCC). Climate Change 2014: Synthesis Report. Contribution of Working Groups I, II and III to the Fifth Assessment Report of the Intergovernmental Panel on Climate Change; Core Writing Team, Pachauri, R.K., Meyer, L.A., Eds.; IPCC: Geneva, Switzerland, 2014; 151p.

3. Iglesias, A.; Garrote, L.; Diz, A.; Schlickenrieder, J.; Martin-Carrasco, F. Re-thinking water policy priorities in the Mediterranean region in view of climate change. Environ. Sci. Policy 2011, 14, 744-757. [CrossRef] 
4. Mediterranean Water Scarcity and Drought Working Group (MED WS\&D WG). Mediterranean Water Scarcity and Drought Report; MED WS\&D WG, European Commission: Brussels, Belgium, 2008; Available online: www.emwis.net/topics/WaterScarcity (accessed on 30 March 2019).

5. Elimelech, M.; Phillip, W.A. The future of seawater desalination: Energy, technology and the environment. Science 2011, 333, 712-717. [CrossRef] [PubMed]

6. Martínez-Alvarez, V.; Martín-Gorriz, B.; Soto-García, M. Seawater desalination for crop irrigation. A review of current experiences and revealed key issues. Desalination 2016, 381, 58-70. [CrossRef]

7. Aznar Sánchez, J.A.; Belmonte Ureña, L.J.; Valera, D.L. Perceptions and acceptance of desalinated seawater for irrigation: A case study in the níjar district (Southeast Spain). Water 2017, 9, 408. [CrossRef]

8. Gao, L.; Yoshikawa, S.; Iseri, Y.; Fujimori, S.; Kanae, S. An economic assessment of the global potential for seawater desalination to 2050. Water 2017, 9, 763. [CrossRef]

9. Martínez-Alvarez, V.; González-Ortega, M.J.; Martín-Gorriz, B.; Soto-García, M.; Maestre Valero, J.F. The use of desalinated seawater for crop irrigation in the Segura River Basin (south-eastern Spain). Desalination 2017, 364, 2-16. [CrossRef]

10. Silber, A.; Israeli, Y.; Elingold, I.; Levi, M.; Levkovitch, I.; Russo, D.; Assouline, S. Irrigation with desalinated water: A step toward increasing water saving and crop yields. Water Resour. Res. 2015, 51, 450-464. [CrossRef]

11. Yermiyahu, U.; Tal, A.; Ben-Gal, A.; Bar-Tal, A.; Tarchitzky, J.; Lahav, O. Rethinking desalinated water quality and agriculture. Science 2007, 318, 920-921. [CrossRef]

12. Shemer, H.; Semiat, R. Sustainable RO desalination-Energy demand and environmental impact. Desalination 2017, 424, 10-16. [CrossRef]

13. Petersen, K.L.; Heck, N.; Reguero, B.G.; Potts, D.; Hovagimian, A.; Paytan, A. Biological and physical effects of brine discharge from the carlsbad desalination plant and implications for future desalination plant constructions. Water 2019, 11, 208. [CrossRef]

14. Ben-Gal, A.; Yermiyahu, U.; Cohen, S. Fertilization and blending alternatives for irrigation with desalinated water. J. Environ. Qual. 2009, 38, 529-535. [CrossRef] [PubMed]

15. Avni, N.; Eben-Chaime, M.; Oron, G. Optimizing desalinated sea water blending with other sources to meet magnesium requirements for potable and irrigation waters. Water Res. 2013, 47, 2164-2176. [CrossRef] [PubMed]

16. Russo, D.; Kurtzman, D. Using desalinated water for irrigation: Its effect on field scale water flow and contaminant transport under cropped conditions. Water 2019, 11, 687. [CrossRef]

17. Burn, S.; Hoang, M.; Zarzo, D.; Olewniak, F.; Campos, E.; Bolto, B.; Barron, O. Desalination techniques-A review of the opportunities for desalination in agriculture. Desalination 2015, 364, 2-16. [CrossRef]

18. Ministerio de Agricultura, Alimentación y Medio Ambiente de España (MAGRAMA). The water Governance System of Spain; MAGRAMA: Madrid, Spain, 2015; 31p.

19. Zarzo, D.; Campos, E.; Terrero, P. Spanish experience in desalination for agriculture. Desalin. Water Treat. 2013, 51, 53-66. [CrossRef]

20. Maestre-Valero, J.F.; Martínez-Granados, D.; Martínez-Alvarez, V.; Calatrava, J. Socio-economic impact of evaporation losses from reservoirs under past, current and future water availability scenarios in the semi-arid Segura basin. Water Resour. Manag. 2013, 27, 1411-1426. [CrossRef]

21. Confederación Hidrográfica de la Cuenca del Segura (CHS). Plan Hidrológico de la Cuenca del Segura 2015-2021; CHS: Murcia, Spain, 2015.

22. Pellicer-Martinez, F.; Martínez-Paz, J.M. Climate change effects on the hydrology of the headwaters of the Tagus River: Implications for the management of the Tagus-Segura transfer. Hydrol. Earth Syst. Sci. 2018, 22, 6473-6491. [CrossRef]

23. Rodriguez-Estrella, T. The problems of overexploitation of aquifers in semi-arid areas: The Murcia Region and the Segura Basin (South-east Spain) case. Hydrol. Earth Syst. Sci. Discuss. 2012, 9, 5729-5756. [CrossRef]

24. Consejería Medio Ambiente y Ordenación del Territorio (CMAOT). Ciclo de Planificación Hidrológica 2015/2021. Demarcación Hidrográfica de las Cuencas Mediterráneas Andaluzas; CMAOT: Sevilla, Spain, 2015.

25. Garcia-Caparros, P.; Contreras, J.I.; Baeza, R.; Segura, M.L.; Lao, M.T. Integral management of irrigation water in intensive horticultural systems of almería. Sustainability 2017, 9, 2271. [CrossRef]

26. Calatrava, J.; Martínez-Grana, D. El valor de uso del agua en el regadío de la cuenca del Segura y en las zonas regables del trasvase Tajo-Segura. Econ. Agrar. Recurs. Nat. 2012, 12, 5-32. [CrossRef] 
27. March, H.; Sairí, D.; Rico-Amorós, A.M. The end of scarcity? Water desalination as the new cornucopia for Mediterranean Spain. J. Hydrol. 2014, 519, 2642-2651. [CrossRef]

28. Swyngedouw, E. Into the sea: Desalination as hydro-social fix in Spain. Ann. Assoc. Am. Geogr. 2013, 103, 261-270. [CrossRef]

29. Desalinated Seawater for Alternative and Sustainable Soilless Crop Production (DESEACROP). Available online: http://www.deseacrop.eu/ (accessed on 3 March 2019).

30. ACUAMED. El uso del agua marina desalinizada en la agricultura de regadío. In Adaptive Measures to Mitigate the Shortage of Water for Irrigated Agriculture in Southeastern Spain, I Jornada Cátedra Trasvase y Sostenibilidad Jose Manuel Claver Valderas; Universidad Politécnica de Cartagena: Cartagena, Spain, 2017.

31. ACUAMED. Informe Anual 2017; Ministerio para la transición ecológica: Madrid, Spain, 2017; 80p.

32. Maestre-Valero, J.F.; González-Ortega, M.J.; Martínez-Álvarez, V.; Martin-Gorriz, B. The role of reclaimed water for crop irrigation in southeast Spain. Water Supply 2019, 19, 1555-1562. [CrossRef]

33. Los Promotores de las Dos Nuevas Desaladoras Reciben Peticiones Para $100 \mathrm{hm}^{3}$. Available online: www. laverdad.es/murcia/promotores-nuevas-desaladoras-20180218010505-ntvo.html (accessed on 3 April 2019).

34. Las Grandes Empresas del Campo de Cartagena se Unen Para Construir Dos Desaladoras. Available online: https:/www.laverdad.es/murcia/grandes-empresas-campo-20171128014131-ntvo.html (accessed on 3 April 2019).

35. Ghalavand, Y.; Hatamipour, M.S.; Rahimi, A. A review on energy consumption of desalination processes. Desalin. Water Treat. 2015, 54, 1526-1541. [CrossRef]

36. Martin-Gorriz, B.; Soto-García, M.; Martínez-Alvarez, V. Energy and greenhouse-gas emissions in irrigated agriculture of SE Spain. Effects of alternative water supply scenarios. Energy 2014, 77, 478-488. [CrossRef]

37. Shaffer, D.L.; Yip, N.Y.; Gilron, J.; Elimelech, M. Seawater desalination for agriculture by integrated forward and reverse osmosis: Improved product water quality for potentially less energy. J. Membr. Sci. 2012, 415-416, 1-8. [CrossRef]

38. Stillwell, A.S.; Webber, M.E. Predicting the specific energy consumption of reverse osmosis desalination. Water 2016, 8, 601. [CrossRef]

39. ACUAMED. Producción y uso de aguas desaladas para regadío. In Working Day on Irrigation Management under Water Scarcity Situation; Centro Nacional de Tecnología de Regadíos: San Fernando de Henares, Spain, 2016.

40. Al-Karaghouli, A.; Kazmerski, L.L. Energy consumption and water production cost of conventional and renewable-energy-powered desalination processes. Renew. Sustain. Energy Rev. 2013, 24, 343-356. [CrossRef]

41. Bolognesi, A.; Bragalli, C.; Lenzi, C.; Artina, S. Energy Efficiency optimization in water distribution systems. Procedia Eng. 2014, 70, 181-190. [CrossRef]

42. Zarzo, D.; Prats, D. Desalination and energy consumption. What can we expect in the near future? Desalination 2018, 427, 1-9. [CrossRef]

43. Asociación Española de Desalación y Reutilización (AEDyR). (Bilbao, Spain). Conclusions of the VII Conference of the Spanish Desalination and Reuse Association, 2009.

44. Semiat, R. Energy issues in desalination processes. Environ. Sci. Technol. 2008, 42, 8193-8201. [CrossRef] [PubMed]

45. Gordon, J.M.; Chua, H.T. Thermodynamic perspective for the specific energy consumption of seawater desalination. Desalination 2016, 386, 13-18. [CrossRef]

46. Shrivastava, A.; Rosenberg, S.; Peery, M. Energy efficiency breakdown of reverse osmosis and its implications on future innovation roadmap for desalination. Desalination 2015, 368, 181-192. [CrossRef]

47. Mazlan, N.M.; Peshev, D.; Livingston, A.G. Energy consumption for desalination-A comparison of forward osmosis with reverse osmosis, and the potential for perfect membranes. Desalination 2016, 377, 138-151. [CrossRef]

48. Peñate, B.; García-Rodríguez, L. Energy optimisation of existing SWRO (seawater reverse osmosis) plants with ERT (energy recovery turbines): Technical and thermoeconomic assessment. Energy 2011, 36, 613-626. [CrossRef]

49. Swyngedouw, E.; Williams, J. From Spain's hydro-deadlock to the desalination fix. Water Int. 2016, 41, 54-73. [CrossRef]

50. Del Villar, A. Energy cost of desalination in the A.G.U.A. program. Investig. Geogr. 2014, 62, 101-112.

51. Ziolkowska, J.R. Is desalination affordable?-Regional cost and price analysis. Water Resour. Manag. 2015, 29, 1385-1397. [CrossRef] 
52. Lapuente, E. Full cost in desalination. A case study of the Segura River Basin. Desalination 2012, 300, 40-45. [CrossRef]

53. Spiritos, E.; Lipchin, C. Desalination in Israel, Water Policy in Israel: Context, Issues and Options; Springer: Dordrecht, The Netherlands, 2013.

54. Bar-Tal, A.; Yermiyahu, U.; Ben-Gal, A.; Schwartz, A.; Faingold, I.; Seligmann, R. Optimization of calcium and magnesium concentrations for fertigation of tomato with desalinated water. Isr. J. Plant Sci. 2017, 63. [CrossRef]

(C) 2019 by the authors. Licensee MDPI, Basel, Switzerland. This article is an open access article distributed under the terms and conditions of the Creative Commons Attribution (CC BY) license (http://creativecommons.org/licenses/by/4.0/). 